\title{
The Pricing Of Thrift Conversions
}

Russ Kashian (E-mail: kashianr@mail.uww.edu), University of Wisconsin-Whitewater Kristen Monaco (E-mail: kmonaco@uwec.edu), California State University Long Beach

\begin{abstract}
This paper aims to explore the conversion of Mutual Thrifts to publicly traded savings institutions. Equity and fairness are important in the mutual thrift conversion process since these firms leave the general community control and placed in specific investor control. As a result, an examination of issue size choice (are there variables that show some thrifts were priced low) and underpricing (are there market results that show a thrift was underpriced) are crucial. We find evidence that the price was chosen in a way to benefit insiders and mutual holding companies.
\end{abstract}

\subsection{Introduction}

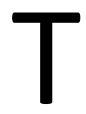

he conversion of Mutual Savings and Loans (thrifts) to public ownership has been used as a strategy to create tangible financial wealth since the moratorium on these conversions expired in 1976. The conversion of a thrift, characterized by non-specific ownership, to a publicly traded company raises questions of fairness and valuation of the demutualization. These questions continue to be relevant in light of the trickle of mutual insurance companies recently taken public. As this trickle becomes a torrent, the history and experience of the mutual thrift can be used to anticipate difficulties.

When a mutual converts to a publicly traded stock corporation, its unique form of ownership is transformed. The nature of the mutual allows depositors to own the firm through participation in the ordinary business of the thrift; the stock form of ownership allows investors to own the firm through the purchase of equity. While the mutual provides for an expanding ownership base through deposits, stock ownership controls ownership through a limited issuance of stock. Ultimately demutualization limits the number of owners to the firm and changes the economic makeup of ownership. As a result, the first concern is a question of fairness in the issuance of stock.

Limited ownership gives each investor a larger share of the undivided accumulated capital of the thrift. Demutualization results in the capital accumulated through the organization's life being distributed to a few depositor/owners, while those depositors unwilling or unable to invest sacrifice their capital interest without compensation. Thus, the very nature of the demutualization evokes concern over equity.

This equity concern is magnified through the valuation choice. The valuation of a thrift is determined through an appraisal by an underwriter resulting in an estimate of the institution's value. When the thrift decides to issue stock, it chooses its valuation based on this appraisal, typically choosing a value within a band of $15 \%$ above or below the appraised value. This choice provides an opportunity for the limited pool of investors to purchase the market value of the firm at a discount, if the issue is "undervalued," with the thrift's board of directors choosing a value at the low end of the band. The concept of undervaluation is predicated on the fact that the value of the firm divided by the IPO price will determine the number of shares available. Lower valuation results in fewer shares issued and, thus, fewer owners participating in the pool of retained earnings and the potential future earnings.

The concern over undervaluing in the conversion of thrifts is considerable due to fairness concerns: it implies potential windfall profits to the few who purchase stock. As a result specific regulations exist regarding the proper assessment of value, however, these regulations allow for an independently derived IPO band. This paper

Readers with comments or questions are encouraged to contact the authors via email. 
addresses the selection of a price within this spectrum of choices. We examine the firm, management and market factors that affect valuation choices for thrift conversion through IPO.

\subsection{Review of Literature}

Since the pricing of IPOs is well researched (Ritter 1995, Michaely and Shaw 1994, Carter and Manchester 1990), it is important to define the unique goals of a thift IPO. Pagano et al (1998) summarize the various benefits a firm gains by going public. These include (1) overcoming borrowing constraints, (2) greater bargaining power with banks, (3) liquidity and portfolio diversification, (4) monitoring, (5) investor recognition, (6) change of control, and (7) windows of opportunity. For thrifts, the reasons to go public are a subset of these.

Peristiani and Wizman (1997) examine the various reasons a thrift will convert to a publicly traded firm. These include monitoring. This regards the demand of the depositor/owners to be allowed a more significant voice in the management of the bank. The second reason, according to Peristiani and Wizman, involves liquidity. By creating a market for the stock and a change in ownership status, the thrift provides management an opportunity to gain stock incentives. The first reason, the creation of external capital market discipline, is contrary in management impact to the second. As a result, the ratio of management ownership may be a significant variable in the determination of price.

Masulis (1987) adds to this by determining that the primary motive for conversions is to obtain additional capital in order to exploit growth opportunities. Without increasing statutory capital needs, a thrift institution is unable to expand its balance sheet.Peristiani and Wizman explore the corresponding potential for overcapitalization. As a result, it is possible that highly capitalized firms (or firms with limited expansion plans) some may consider their need for funds in an inverse relationship to price.

The conversion of thrifts to a publicly traded firm requires an independent appraisal of the pro forma value of the converting thrift. Once a thrift has determined its value through an appraisal, it is possible that it may price the aggregate initial public offering in a band between $15 \%$ below the lowest appraised value and $15 \%$ above the midpoint appraised value (FHLBB, 1983). This midpoint value implies that the appraiser estimates are accurate within a boundary of $15 \%$. However, some thrifts price their IPO above this band.

Given the discretion that thrifts have over the value of stock issues within the band, what issues does the thrift face when choosing the specific value of shares issued in the IPO - i.e. should thrifts choose a valuation in the high end of the band or the low end. Clearly, choosing a valuation in the high end of the band leads to more capital infused to the thrift, which should result in a stronger future for the institution. In addition, choosing the valuation at the high end of the band will yield additional investment opportunity for the institution. Finally, choosing a valuation in the high end of the band may create "fairness" or mitigate inequality caused by undervaluation, which results in the stock being sold to investors (including insiders) at a discount. In this case, the value of the mutual is not being sold by the many to the few at a discount, allowing for immediate gains to investors.

Unlike typical IPOs, the proceeds from the conversion are not distributed to the mutual owners. Due to this, maximum pricing is not guided by the self-interest of an individual, however, underpricing of the shares may have appeal to those buying the newly issued stock. The funds raised by the conversion are infused into the equity capital of the institution. As a result, the conversion process provides a dramatic increase in capital for the newly formed stock institution.

Concerns about underpricing center around the fact that conversion provides these underpriced shares to insiders. The issue of underpricing is one of the most extensively documented anomalies in financial economics (see McDonald and Fisher (1972), Logue (1973), Ibbotson (1975), Ritter (1984), Ritter (1991), Chemmanur (1993), Loughran and Ritter (1995)). Underpricing is regarded as the first day run-up in the stock and is typically measured as the percent difference between the first day closing price $\left(\mathrm{P}_{1}\right)$ and the initial primary market price $\left(\mathrm{P}_{0}\right),\left(\left(\mathrm{P}_{1}-\mathrm{P}_{0}\right) /\right.$ $\mathrm{P}_{0}$, see Beatty and Ritter, 1986). This initial consideration omits the possibility that opening day prices reflect the momentum of the specific day. In response, this dependent variable is often corrected to account for market forces 
through the inclusion of the NASDAQ index (for example Carter, Dark, and Singh, 1998). While the general concern over underpricing is of interest in the overall market, it is of particular concern with respect to thrift conversions. Other firms may only have a few owners who are directly involved in the pricing decision, while thrifts have many owners who have little influence in the pricing decision.

In the literature on inter-industry IPO returns, Ibbotson, Sindelar, and Ritter (1988) report an average initial return of 16.4\%. Carter, Dark and Singh (1998) report an average market adjusted initial return of $8.08 \%$. Average initial return is computed from the offer price to the closing price on the first day of trading in the secondary market. It is market adjusted by subtracting contemporaneous index value-weighted market returns. It is this historic windfall that creates concern over the fairness of equity pricing. Prior literature in thrift conversions (Maksimovic and Unal (1993), Jordan, Verbrugge, and Burns (1988), and Masulis (1987)) clearly show positive after-market one day returns.

Although over 2000 thrifts have converted since the 1970s, research has mainly focused on the issue of underpricing as a function of subsequent performance. This paper focuses on pre-market pricing. While "underpricing" is often used as an ex post explanation, this paper regards "underpricing" relative to the primary market.

In an attempt to estimate value, Unal (1997) reviews the government supervised pricing process of a thrift conversion, using case studies to explain the difficulties in pricing. Typical valuation estimates grow out the pool of available information and investor liquidity (Bodie, et al, 1996). Since the valuation algorithm has no room for expectations in its pool of information, it uses comparable firms as proxies. The stock price of the comparable firms provides a mechanism to gauge growth and market potential of the thrift. However, since these firms are one step removed from the thrift, it is possible that this still allows for the possibility of market underpricing.

The possibility of underpricing provides for critical analysis of the process; underpricing is determined to exist due to fundamental flaws in the calculation methodology. Unal determines that the flaw is centered on the reluctance to factor into the equation accurate expectation of growth. As a result, despite the infusion of considerable capital, there is premium for expectations. Unal looks at the pricing according to the static assumptions of the appraisal model. This model is then expanded upon with the inclusion of subsequent pricing to determine the concept of underpricing.

Maksimovic and Unal (1993), conduct two econometric approaches to pricing analysis. Using data from 1980 to 1988, they review the choice of a price and the subsequent returns. They model the choice of valuation within the appraisal spectrum according to a few internal and external variables. The variables are limited to the initial level of management control of the IPO, the initial level of priority ownership, and the proportional changes in both the thrift index and ten-year bond index lagged six weeks for the date of the public offer.

When fully examined, the earlier literature concentrates on underpricing. However, not all thrift conversions witness the same explosive growth. As a result, there is room to question the actual choice of price: institutions, which appear similar, may not be priced the same. This work attempts to define those differences. These differences may be internal, in terms of balance sheet composition, or external, in terms of market and economic timing

\subsection{Data and Model}

This paper seeks to model the initial pricing determination and its relationship to the appraised value. In accordance with government regulations, appraisers provide three sets of estimates. These estimates are based on a modified valuation based on earnings, a modified valuation based on retained earnings, and a modified valuation based on asset size. Given the appraisals, the offer price is set within $15 \%$ above and $15 \%$ below this midpoint. Given an appraisal and a band to work within, there exists a question regarding the final pricing choice. 
Since the unique structure of a thrift prevents insiders from sharing in the underlying value of the firm, conversion provides an opportunity to share in future value. However, by underpricing, the insiders create an opportunity to regain value created in the past. It is this concern that separates this question from other IPO's. In a traditional IPO, the insiders of a firm are provided an opportunity to collect on this value.

To construct these models we use a data set provided by SNL Securities Inc. and the database of Edgar Online. SNL collected most of this data from the S-1 filings produced by mutual thrifts in announcement of their intention to go public. All balance sheet and income statement data came from these sources. Balance sheet values were obtained by SNL from the original IPO filings and reflect the previous fiscal year to IPO. In addition, information regarding the offering (lead underwriter, high and low valuation, ticker symbols, gross and net IPO proceeds, number of shares issued, date of stock issuance, and percent of stock sold to insiders) was provided by either SNL or Edgar Online. The proprietary thrift stock index and subsequent thrift mergers or commercial bank conversions are provided by SNL. Bond Index information is retrieved from the Federal Reserve Bank's "releases" website.

The dependent variable in this model is the ratio of IPO proceeds to the mean appraised value, referred to as the "price" of the IPO, but better expressed as the choice of value of the conversion within the band. The "price" ranges from $40 \%$ to $165 \%$ of appraised value.

Variables included in the model to explain the pricing choice are measures of firm performance as well as market measures. The measures of firm performance include the ratios of capital to assets and income to assets. A priori, we would expect the coefficients on the capital and income ratios to be positive, reflecting positive returns to past and current profitability.

Also included are measures of the percent of shares retained by insiders and a the percent of mutual company ownership. A priori we anticipate a negative sign on the coefficient of the percent of shares retained by insiders, as there exists opportunity for arbitrage by pricing low to reap returns for insiders. Finally, we include controls for year of conversion. The omitted year is 2000, used as a benchmark. Descriptive statistics on these variables are presented in Table 1.

Table 1: Descriptive Statistics $(\mathbf{n}=\mathbf{2 5 0})$

\begin{tabular}{|l|c|c|}
\hline Variable & Mean & $\begin{array}{c}\text { Standard } \\
\text { Deviation }\end{array}$ \\
\hline Price & 1.208 & 0.170 \\
\hline Percent Insider & 7.345 & 6.625 \\
\hline Percent Mututal Holding Company & 0.120 & 0.326 \\
\hline Thrift Index & 521.56 & 195.25 \\
\hline Bond Rate & 6.131 & 0.752 \\
\hline Capital/Assets & 0.108 & 0.698 \\
\hline Income/Assets & 0.0065 & 0.007 \\
\hline & & \\
\hline Year & Percent & \\
\hline 2000 & $3.6 \%$ & \\
\hline 1999 & $10.0 \%$ & \\
\hline 1998 & $21.2 \%$ & \\
\hline 1997 & $13.2 \%$ & \\
\hline 1996 & $23.2 \%$ & \\
\hline 1995 & $28.8 \%$ & \\
\hline
\end{tabular}


The model can thus be rewritten as:

price $=\alpha+\beta_{1}$ percent $\_$insider $+\beta_{2}$ mutual_holding $+\beta_{3}$ thrift_index $+\beta_{4}$ bond_rate $+\beta_{5}$ capital $/$ asssets + $\beta_{6}$ income/assets $+\delta$ year_dummy $+\varepsilon$

where $\varepsilon$ is the error term.

There is a potential problem with using OLS to estimate this model, given that the percent sold to insiders is undoubtedly not and exogenous variable with respect to price. The choice by insiders to purchase shares is undoubtedly an endogenous choice, driven by such factors as other potential investment opportunities for thrift owners. For managers of the thrift, who also may have a role in choosing the "price" of the issue, considerations such as perquisites (such as their salary) may play a role. Due to this endogeneity problem, we model the estimation of equation 1 using Two Stage Least Squares, where the percent of shares purchased by insiders can be expressed as:

percent_insider $=\alpha+\beta_{1}$ ceo_compensation $+\beta_{2}$ thrift_index $+\beta_{3}$ bond_rate +

$\beta_{4}$ assets $+v$

where $v$ represents the error term.

Thus, the percentage of the shares is a function of the size of the firm, proxied by assets, the pay rate of the managers, proxied by the compensation of the CEO and other rates of return in the market, proxied by the thrift index and the bond rate.

The results of Two Stage Least Squares estimation of equation 1 are presented in Table 2. The significant variables include percent of shares purchased by insiders, percent of shares held by the mutual holding company, the thrift index and time.

The negative relationship between percent retained by insiders provides evidence of insider benefit from underpricing. If insider holding is substantial then there is an incentive to underprice to provide capital gains to the stockholders. The inverse relationship between valuation and holding company share may be due to a fear of secondary offerings provided by the holding company. In addition, large holding company shares may limit the potential for investor control, due to the blocking power of the holding company.

There is a positive relationship between price and the thrift index. This is expected given that an increase in the thrift index represents increased profitability of financial institutions. If financial institutions are generally performing well, there is an incentive for the thrift to price high in order to gain excess capital funds for future expansion.

Finally the coefficients on the years 1995-1997 are positive and significant. Given that the omitted year is 2000, these coefficients imply that thrift conversions were priced higher in the mid-1990s than in the year 2000, all else equal. This is not surprising given that conversion activity was higher in the mid-1990s and investment in financial institutions was more popular at this time. In the later 1990s and 2000, investment funds were directed more towards technology stocks than financials. 
Table 2: Pricing in the Primary Market

\begin{tabular}{|c|c|}
\hline Explanatory Variable & Coefficient \\
\hline Percent Insiders & $\begin{array}{l}-0.0083 * \\
(-2.34)\end{array}$ \\
\hline Mutual Company Ownership & $\begin{array}{l}-0.0797 * \\
(-2.49)\end{array}$ \\
\hline Thrift Index & $\begin{array}{l}0.0008 * * \\
(5.83)\end{array}$ \\
\hline Bond Index & $\begin{array}{l}-0.0141 \\
(-0.72)\end{array}$ \\
\hline Capital/Assets & $\begin{array}{l}0.0131 \\
(0.10)\end{array}$ \\
\hline Income/Assets & $\begin{array}{l}0.5580 \\
(0.42)\end{array}$ \\
\hline 1999 & $\begin{array}{l}0.0154 \\
(0.26)\end{array}$ \\
\hline 1998 & $\begin{array}{l}0.0493 \\
(0.81)\end{array}$ \\
\hline 1997 & $\begin{array}{l}0.2657 * * \\
(4.85)\end{array}$ \\
\hline 1996 & $\begin{array}{l}0.3841 * * \\
(7.11)\end{array}$ \\
\hline 1995 & $\begin{array}{l}0.4362 * * \\
(7.48)\end{array}$ \\
\hline Constant & $\begin{array}{l}0.6983 \\
(4.49)\end{array}$ \\
\hline $\begin{array}{l}\text { R-Squared } \\
\mathrm{N}\end{array}$ & $\begin{array}{l}0.36 \\
247\end{array}$ \\
\hline
\end{tabular}

\subsection{Summary and Conclusions}

Equity and fairness are concerns in the mutual thrift conversion process since the ownership of the firm changes from depositor-owned to share-holder-owned. These issues are typically examined by exploring whether thrift conversions are undervalued or "underpriced." Our study considers issues of pricing in the primary market instead to consider what factors play a role in the management's choice of thrift valuation. It is generally considered in the insiders' interests to choose a low valuation, or underpricing, which results in immediate gains to shareholders. Choosing a high value is typically considered "fairer" as it allows the thrift to expand through increased capital and allows for more depositors to become shareholders as more shares of the thrift are issued.

We find evidence of strategic underpricing. There is a negative relationship between both insider ownership and mutual and price, implying that thrifts may underprice in order to provide immediate benefits to insiders. There is a positice relationship between the thrift index and price. As the thrift index increases (which is typically due to profitability of financial institutions) the price of the conversion increases as well. This is expected given the "efficient market hypothesis" that the price of a stock is a function of expectations of future returns.

\subsection{Suggestions for Future Research}

While this paper re-enters the issue of pricing strategy and underpricing in the primary market, it leaves open further research into the long-term implications of pricing. Are underpriced thrifts more likely to merge or be taken private? This question begs serious investigation in a market where small thrifts are seen as expansion fodder 
for larger institutions. Finally, underpricing can be recalculated using long-term returns (three to five years) rather than short term returns. This provides an opportunity to separate the investor from the speculator.

\section{References}

1. Beatty, Randolph P. and Jay R. Ritter, "Investment Banking, Reputation, and the Underpricing of Initial Public Offerings," Journal of Financial Economics, Vol. 15, No. 1-2, pp. 213-232, 1986.

2. Bodie, Zvi, Alex Kane, and Alan J. Marcus, Investments, Irwin Press, Chicago, IL, 1996.

3. Carter, Richard B., Frederick H. Dark, and Ajai K. Singh, "Underwriter Reputation, Initial Returns, and the Long-Run Performance of IPO Stocks," The Journal of Finance, Vol. 53, No. 1, pp. 285-311, 1998.

4. Carter, Richard B. and Steven Manaster, "Initial Public Offerings and Underwriter Reputation," Journal of Finance Vol. 45, No. 4, pp.1045-1067, 1990.

5. Chemmanur, Thomas J., "The Pricing of Initial Public Offerings: A Dynamic Model with Information Production," Journal of Finance, Vol. 43, No. 1, pp. 285-304, 1993.

6. Federal Home Loan Bank Board (FHLBB), "Guidelines for Appraisal Reports for the Valuation of Savings and Loan Association and Savings Banks Converting from Mutual to Stock Form of Organization, Office of Economic Research, 1983.

7. Ibbotson, Roger G., "Price Performance of Common Stock New Issues," Journal of Financial Economics, Vol. 2, No. 3, pp. 235-272, 1975.

8. Ibbotson, Roger G., Jody L. Sindelar, and Jay Ritter, "Initial Public Offerings," Journal of Applied Corporate Finance, Vol. 1, pp. 37-45, 1988.

9. Jordan, Bradford D., James A. Verbrugge, and Richard M. Burns, "Return to Initial Shareholders in Savings Institution Conversions," Journal of Financial Research, Vol. 11, No. 2, pp. 125-136, 1988.

10. Logue, Dennis E., "On the Pricing of Unseasoned Equity Issues: 1965-1969," Journal of Financial and Quantitative Analysis, Vol. 8, No. 1, pp. 91-103, 1973.

11. Loughran, Tim and Jay R. Ritter, "The New Issues Puzzle," Journal of Finance, Vol. 50, No. 1, pp. 23-51, 1995.

12. Maksimovic, Vojislav and Haluk Unal, "Issue Size Choice and "Underpricing" in Thrift Mutual-to-Stock Conversions," Journal of Finance, Vol. 48, No. 5, pp. 1659-1692, 1993.

13. Masulis, W. Ronald., "Changes in Ownership Structure: Conversions of Mutual Savings and Loans to Stock Charter," Journal of Financial Economics, Vol. 18, No. 1-2, pp. 29-59, 1987.

14. McDonald, John G. and A. K. Fisher, "New Issue Stock Price Behavior," Journal of Finance, Vol. 27, No. 1, pp. 97-102, 1972.

15. Michaely, Roni and Wayne H. Shaw, "The Pricing of Initial Public Offerings: Tests of Adverse-Selection and Signaling Theories", Review of Financial Studies, Vol. 7, No. 2, pp. 279-319, 1995.

16. Pagano, Marco, Fabio Panetta, and Luigi Zingales, "Why Do Companies Go Public? An Empirical Study," Journal of Finance, Vol. 53, No. 1, pp. 27-64, 1998.

17. Peristiani, Stavros and Thiery A. Wizman, "Mutual-to-Stock Conversions in the Thrift Industry in the 1990s," Journal of Economics and Business, Vol. 49, No. 2, pp. 95-116, 1997.

18. Ritter, Jay R., "The Long Run Performance of Initial Public Offerings," Journal Of Finance, Vol. 46, No. 1, pp. 3-28, 1991.

19. Ritter, Jay R., “The Hot Issue Market of 1980,” Journal of Business, Vol. 57, No. 2, pp. 215-240, 1984.

20. Titman, Sheridan and Brent Trueman, "Information Quality and the Valuation of New Issues," Journal of Accounting and Economics, Vol. 8, No. 2, pp. 159-172, 1986.

21. Unal, Haluk, "Regulatory Misconceptions in Pricing Thrift Conversions: A Closer Look at the Appraisal Process," Journal of Financial Services Research, Vol. 11, No. 3, pp. 239-254, 1997. 
Notes 